\title{
Effects of green and nitrogen fertilization on the yield and yield components of irrigated winter beans
}

\section{Adubação verde e nitrogenada sobre os componentes de produção e produtividade do feijoeiro de inverno irrigado}

\author{
Lucas Martins Garé ${ }^{*}$; Letícia Martins e Martins²; Orivaldo Arf ${ }^{3}$; Fernando de \\ Souza Buzo ${ }^{1}$; José Roberto Portugal ${ }^{4}$; Nayara Fernanda Siviero Garcia ${ }^{5}$; Tayná \\ Lara Serantoni da Silveira ${ }^{2}$; Leticia Zylmennith de Souza Sales ${ }^{1}$
}

\section{Highlights:}

Consortium treatments produced higher amounts of dry matter in NTS.

Regarding $\mathrm{N}$ rates, the dry matter of plants adjusted to an increasing linear function.

Vegetable residues had no influence on bean grain yield.

Only the first crop responded to the application of $\mathrm{N}$ in coverage.

\begin{abstract}
The contribution of plant residues to the soil is an essential requirement for the success of no-tillage systems, especially in areas with a tropical climate where the organic material decomposition rate is high. The type of straw present on the soil surface can influence the culture implanted subsequently, mainly with regard to the availability of nitrogen $(\mathrm{N})$. The objective of this study was to investigate the effect of cultural remains of maize (exclusive or intercropped with cover crops) on the development and productivity of the common bean grown in succession and fertilized with different $\mathrm{N}$ doses. The experimental design was a randomized block arranged in a factorial scheme $(5 \times 4)$, with four replications. The treatments consisted of combinations of cultural remains of exclusive maize, maize + Crotalaria spectabilis, maize + Cajanus cajan, maize + Canavalia ensiformis, and maize + Urochloa ruziziensis cultivated previously and of four $\mathrm{N}$ rates $\left(0,40,80\right.$, and $\left.120 \mathrm{~kg} \mathrm{ha}^{-1}\right)$ applied to bean crops. The plots consisted of seven lines of $7.5 \mathrm{~m}$ length with $0.45 \mathrm{~m}$ spacing between the lines. The evaluated parameters were: dry matter of the plant cover, dry matter of the aerial part (beans), production components, weight of 100 grains, and grain yield. The intercropping of maize and cover crops promoted an increase in dry matter over the soil, compared to the exclusive maize crop. There was an increase in the dry matter of bean plants with the increase in $\mathrm{N}$ rates in the two years of cultivation; regarding productivity, there was an increment only in the first year of cultivation. The maize consortium with cover plants provided adequate soil cover, but did not influence the productivity of beans cultivated in succession in the two years of cultivation.
\end{abstract}

Key words: Phaseolus vulgaris L. Cover crops. Consortium cultivation. No-till system.

\footnotetext{
${ }^{1}$ Discentes, Curso de Mestrado do Programa de Pós-Graduação em Agronomia (Sistemas de Produção), Departamento de Fitotecnia, Tecnologia de Alimentos e Sócio Economia, Universidade Estadual Paulista, UNESP, Ilha Solteira, SP, Brasil. E-mail: lucasmgare@gmail.com; fsbuzo@gmail.com; leticia_zylmennith@hotmail.com

2 Eng ${ }^{\text {as }}$ Agr ${ }^{\text {as }}$, UNESP, Ilha Solteira, SP, Brasil. E-mail: le.mmartins2@gmail.com; taynalserantoni@gmail.com

3 Prof. Dr., Departamento de Fitotecnia, Tecnologia de Alimentos e Sócio Economia, UNESP, Ilha Solteira, SP, Brasil. E-mail: arf@agr.feis.unesp.br

4 Pós-Doutorando, Departamento de Produção e Melhoramento Vegetal, Faculdade de Ciências Agronômicas, UNESP, Botucatu, SP, Brasil. E-mail: jr portugal@hotmail.com

5 Discente, Curso de Doutorado do Programa de Pós-Graduação em Agronomia, Sistemas de Produção, Departamento de Fitotecnia, Tecnologia de Alimentos e Sócio Economia, UNESP, Ilha Solteira, SP, Brasil. E-mail: nayaragarcia.agro@gmail.com Author for correspondence
} 


\section{Resumo}

O aporte de resíduos vegetais ao solo é um dos requisitos essenciais para o sucesso do plantio direto, principalmente em áreas de clima tropical, cuja taxa de decomposição do material orgânico é elevada. O tipo de palha presente na superfície do solo pode influenciar a cultura implantada na sequência, principalmente ao que diz respeito à disponibilização de nitrogênio (N). Sendo assim, objetivou-se estudar o efeito dos restos culturais de milho (Zea mays L.) exclusivo ou consorciado com plantas de cobertura no desenvolvimento e produtividade do feijoeiro (Phaseolus vulgaris L.) cultivado em sucessão e adubado com doses de N. O delineamento experimental foi o de blocos casualizados disposto em esquema fatorial $5 \times 4$, com quatro repetições. Os tratamentos foram constituídos pela combinação do efeito dos restos culturais de milho exclusivo; milho + Crotalaria spectabilis; milho + Cajanus cajan; milho + Canavalia ensiformis; milho + Urochloa ruziziensis, cultivadas anteriormente e, por quatro doses de $\mathrm{N}$ aplicadas em cobertura na cultura do feijão $\left(0,40,80\right.$ e $\left.120 \mathrm{~kg} \mathrm{ha}^{-1}\right)$. As parcelas foram constituídas por 7 linhas de 7,5 $\mathrm{m}$ de comprimento com espaçamento de $0,45 \mathrm{~m}$. Os parâmetros avaliados foram: matéria seca da cobertura vegetal, matéria seca da parte aérea (feijão), componentes de produção, massa de 100 grãos e produtividade de grãos. O consórcio entre milho e plantas de cobertura promoveu aumento da matéria seca sobre o solo, comparado ao cultivo de milho exclusivo. Houve incremento na matéria seca de plantas de feijão com as doses crescentes de $\mathrm{N}$ nos dois anos de cultivo e para a produtividade houve incremento somente no primeiro ano de cultivo. O consórcio do milho com plantas de cobertura proporcionou adequada cobertura do solo, porém não influenciou a produtividade do feijoeiro cultivado em sucessão nos dois anos de cultivo.

Palavras-chave: Phaseolus vulgaris L. Cultivo consorciado. Plantas de cobertura. Sistema plantio direto.

\section{Introduction}

The common bean (Phaseolus vulgaris L.) is a crop of great importance in the Brazilian economy, both for its production value and its social function, being a source of income and subsistence for thousands of families. Brazil is the world's third largest bean producer, falling behind Myanmar and India (Food and Agriculture Organization of the United Nations [FAO], 2017).

Owing to the great ease with which the common bean can be cultivated under various edaphoclimatic conditions, it is produced almost all over the country under diverse production systems, from subsistence agriculture to technified crops. The national production of beans in the 2017/18 harvest was approximately 3.12 million tons, with an average yield of 982 $\mathrm{kg} \mathrm{ha}^{-1}$ (Companhia Nacional de Abastecimento [CONAB], 2019). Bean yield in Brazil is low; the use of appropriate cultivation techniques allows for the possibility to increase grain yield.

Among these techniques, the no-tillage system (NTS) is a sustainable technology for grain production in agricultural systems. This system provides several improvements on the chemical, physical, and biological attributes of soil, such as increased porosity, reduced erosion, and increased organic matter content (Leite, Mendonça, Machado, \& Matos, 2003; Rao \& Li, 2003) and soil microbial functions (Steenwerth \& Belina, 2008).

The type of mulch present on the soil surface can influence crop management and especially nitrogen fertilization (Andrioli, Beutler, Centurion, Andrioli, \& Coutinho, 2008; Bordin, Farinelli, Penariol, \& Fornasieri, 2003). At the beginning of straw decomposition, the immobilization of nutrients and organic matter in the soil tends to be higher than mineralization (Siqueira, Piccolo, Venzke, Feigl, \& Cerri, 2010). Thus, in NTS, there may be a need to use higher nitrogen $(\mathrm{N})$ doses as a function of the decomposition rate and the carbon/nitrogen $(\mathrm{C} / \mathrm{N})$ ratio of the straw. Intercrop cultivation of green manures in the maize crop is capable of producing dry plant matter with a lower $\mathrm{C} / \mathrm{N}$ ratio, which together with the crop residues of the maize plants may benefit the development and productivity of winter beans cultivated in succession. In addition, depending on the type of straw in the area where the bean crop is planted, there may be reduced use of nitrogen fertilizers, especially in the case of legumes. 
Nutritional input is fundamental, especially N, which is generally the nutrient plants demand the most. As beans are nutritionally demanding crops, adequate fertilization is essential in fulfilling the nutritional needs of the culture. Yield increases can be promoted by nitrogen fertilization that also serves as a means of increasing the protein content of beans (C. D. B. Andrade, Patroni, Clemente, \& Scapim, 2004; Gomes, Sá, \& Valério, 2008; Silva, Lemos, \& Tavares, 2006; Soratto, Crusciol, Silva, \& Lemos, 2005).

Thus, the objective of this study was to examine the effect of crop residues of maize (exclusive or intercropped with cover crops) on the development and productivity of beans cultivated in succession and fertilized with different $\mathrm{N}$ rates.

\section{Materials and Methods}

The study was carried out in 2014 and 2016 in an experimental area belonging to Universidade Estadual Paulista (UNESP), Ilha Solteira Campus, located in Selvíria - MS, Brazil $\left(20^{\circ} 20^{\prime} 53^{\prime \prime} \mathrm{S}\right.$ $\left.51^{\circ} 24^{\prime} 02^{\prime \prime} \mathrm{W}\right)$, with an approximate elevation of $335 \mathrm{~m}$. The soil in the area is classified as a typical clayey dystrophic Red Latosol (Santos et al., 2018), originally occupied by cerrado vegetation.

According to the Köppen classification, the region's climate is Aw with an average annual temperature of $23^{\circ} \mathrm{C}$, an average annual rainfall of $1,322 \mathrm{~mm}$, and an average annual relative humidity of $66 \%$ (Alvares et al., 2013). Data regarding rainfall and minimum and maximum temperatures during the experiment are presented in Figure 1.
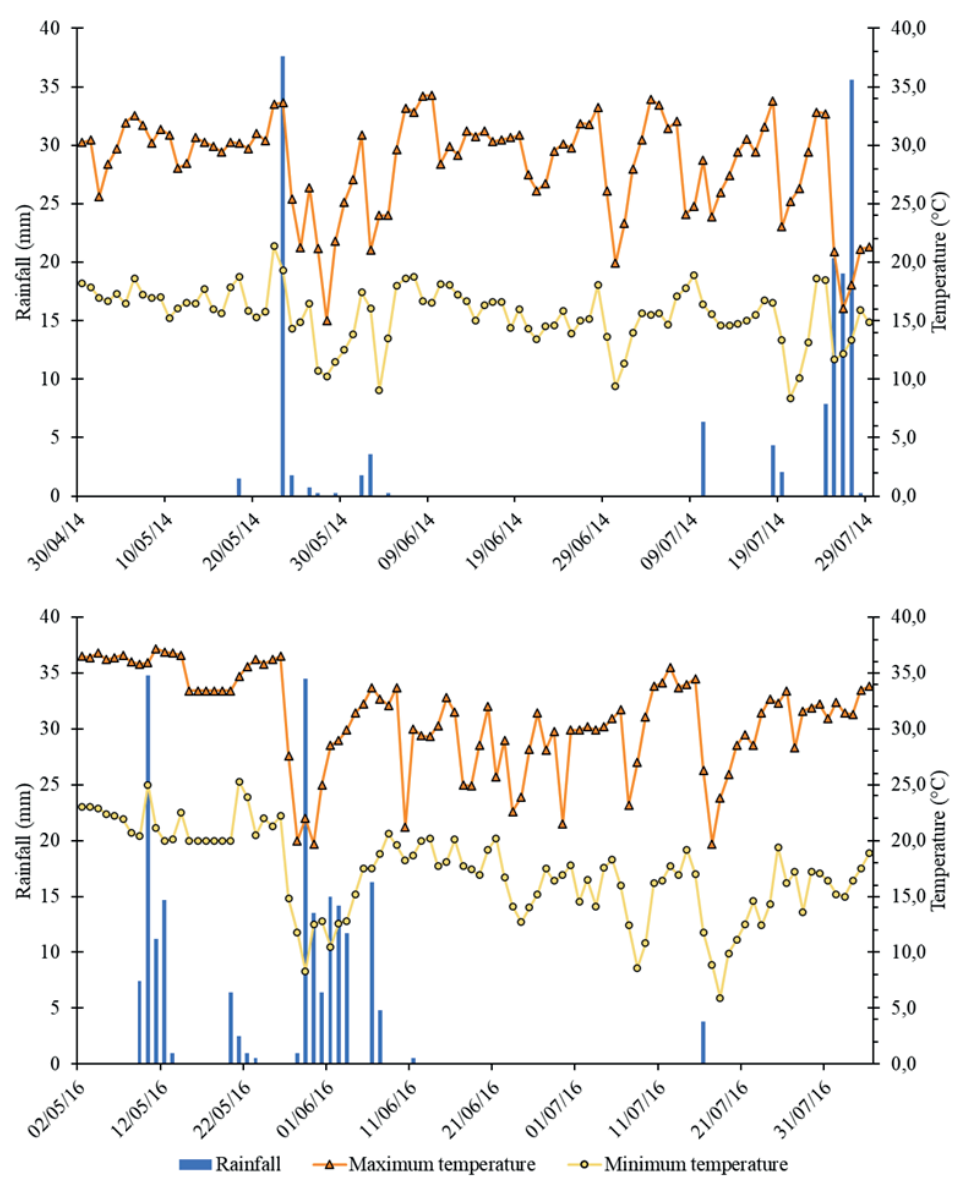

Figure 1. Average daily values of rainfall $(\mathrm{mm})$ and maximum and minimum temperatures $\left({ }^{\circ} \mathrm{C}\right)$ collected during the experiment. Selvíria - MS, 2014 and 2016. Source: Fazenda de ensino, pesquisa e extensão (FEPE) Meteorological Station. 
Prior to the start of the experiment, chemical characterization of the soil in the $0.00-0.10 \mathrm{~m}, 0.10$ $0.20 \mathrm{~m}$, and $0.20-0.40 \mathrm{~m}$ layers was performed. The results of soil fertility analysis, according to the methodology proposed by Raij, Andrade, Cantarella and Quaggio (2001), are presented in Table 1.

\section{Table 1}

Chemical attributes of the soil in the experimental area, at depths of $0-0.10,0.10-0.20$, and $0.20-0.40 \mathrm{~m}$. in Selvíria - MS, 2013

\begin{tabular}{ccccccccccc}
\hline Profundity & $\mathbf{P}_{\text {resin }}$ & $\mathbf{O . M}$ & $\mathbf{p H}$ & $\mathbf{K}$ & $\mathbf{C a}$ & $\mathbf{M g}$ & $\mathbf{H}+\mathbf{A l}$ & $\mathbf{S . B .}$ & $\mathbf{C E C}$ & $\mathbf{V}$ \\
\hline$(\mathrm{m})$ & $\left(\mathrm{mg} \mathrm{dm}^{-3}\right)$ & $\left(\mathrm{g} \mathrm{dm}^{-3}\right)$ & $\left(\mathrm{CaCl}_{2}\right)$ & $-----------------\mathrm{mmol}_{\mathrm{c}} \mathrm{dm}^{-3}---------------~$ & $(\%)$ \\
\hline $0.00-0.10$ & 22 & 23 & 5.7 & 3.7 & 35 & 26 & 21 & 64.7 & 85.7 & 75 \\
$0.10-0.20$ & 18 & 18 & 5.1 & 2.3 & 21 & 17 & 28 & 40.3 & 68.3 & 59 \\
$0.20-0.40$ & 6 & 14 & 4.6 & 1.3 & 11 & 8 & 31 & 20.3 & 51.3 & 40 \\
\hline
\end{tabular}

Source: Laboratory of Soil and Plant Tissue Fertility (UNESP - Ilha Solteira). O.M.: organic matter; S.B: sum of bases; CEC: cation exchange capacity; V: base saturation.

The experimental design was in randomized blocks arranged in a $5 \times 4$ factorial scheme with four replications. The treatments consisted of a combination of the effect of the exclusive maize crop residues, maize + Crotalaria spectabilis, maize + Cajanus cajan, maize + Canavalia ensiformis, and maize + Urochloa ruziziensis previously cultivated and of four $\mathrm{N}$ rates applied on the cover crops $(0,40$, 80 , and $\left.120 \mathrm{~kg} \mathrm{ha}^{-1}\right)$. The plots consisted of seven lines of $7.5 \mathrm{~m}$ length with $0.45 \mathrm{~m}$ spacing between the lines. The five central lines were considered as the useful area.

The maize crops were installed on November 18, 2013 and November 9, 2015, using the simple and early hybrid Dow 2B710 PW. Maize in the exclusive cultivation was planted with spacing of $0.90 \mathrm{~m}$ between the rows and a density of five plants per linear meter. During field cultivation, Crotalaria spectabilis, Cajanus Cajan, Canavalia ensiformis, and Urochloa ruziziensis cover crops were sown in open furrows between rows, at a distance of $0.45 \mathrm{~m}$ from the maize lines, using 30 viable seeds meter $^{-1}$, 15 viable seeds meter ${ }^{-1}, 7$ viable seeds meter ${ }^{-1}$, and 8 $\mathrm{kg} \mathrm{ha}^{-1}$, respectively.

After harvesting the exclusive maize and intercropped grains, the plants present in the area were desiccated with the herbicide glyphosate [1,560 $\mathrm{g} \mathrm{ha}^{-1}$ of the active ingredient (a.i.)].

Bean sowing occurred 15 days after the desiccation of the area using the BRS Notável (season 2014) and BRS Estilo (season 2016) cultivars with type II plants and carioca grains, which are recommended for the state of Mato Grosso do Sul (Melo et al., 2012). Notably, after the cultivation of the first winter bean crop (2014), highland rice was sown in the summer and wheat in the winter (2015); then, in the summer of 2016, maize was sown in an intercropping system with cover plants and a bean crop was sown in the following winter. Sowing was carried out mechanically in the NTS on April 30, 2014 and May 2, 2016, using the amount of seeds required to produce a population of approximately 200,000 plants ha ${ }^{-1}$. In the two years of the experiment, the seeds were treated shortly before sowing with carboxin + thiram $(60+60 \mathrm{~g}$ of a.i. $100 \mathrm{~kg}^{-1}$ seeds). After seed drying, Rhizobium tropici and Azospirillum brasilense strains were inoculated using $200 \mathrm{~g}$ and $200 \mathrm{~mL}$ of commercial inoculants per $100 \mathrm{~kg}$ of seeds, respectively.

In both seasons, $200 \mathrm{~kg} \mathrm{ha}^{-1}$ of the $08-28-16$ (NPK) formulation were used for the mineral fertilization of the sowing furrows. This amount was calculated 
according to the chemical characteristics of the soil, the expected yield of 2.5 to $3.5 \mathrm{t} \mathrm{ha}^{-1}$, and the recommendations of Ambrosano, Wutke, Bulisani, and Cantarella (1997). Nitrogen fertilization, in the form of $\mathrm{N}$ urea, was applied in both years of cultivation in the development phase $\mathrm{V}_{4-4^{4}}$. After the application of $\mathrm{N}$, the area was irrigated with a blade of approximately $15 \mathrm{~mm}$, aiming to reduce volatilization losses.

In the first year of cultivation, weed control was carried out with the application of the herbicide bentazon ( $720 \mathrm{~g} \mathrm{ha}^{-1}$ of a.i.) at 22 days after plant emergence. In the second year, the herbicide fomesafen $\left(225 \mathrm{~g} \mathrm{ha}^{-1}\right.$ of a.i.) was applied 20 days after emergence.

When required, water was supplied by a fixed sprinkler irrigation system. During crop development, crop coefficient $(\mathrm{Kc})$ values, similar to those recommended by Doorenbos and Kassan (1988), were used for water management at the $V_{0}$ - $\mathrm{V}_{1}(\mathrm{Kc}=0.30), \mathrm{V}_{3}-\mathrm{V}_{4}(\mathrm{Kc}=0.70), \mathrm{R}_{5}-\mathrm{R}_{7}(\mathrm{Kc}$ $=1.05), R_{8}(0.75)$, and $R_{9}(0.25)$ stages. The other crop and phytosanitary treatments used were those normally recommended for winter bean crops in the studied region.

Seedling emergence occurred 6 days after sowing in both crops. In the first year, harvest was conducted on July 29, 2014, 85 days after emergence; in the second year, harvest was conducted on August 5, 2016, 96 days after emergence.

The following evaluations were carried out during the experiment:

Dry cover crops: after a mechanical disintegrator was used to manage the maize plants and cover crops, the dry matter mass production of the aerial part was evaluated. Random samplings were performed with a $0.5 \times 0.5 \mathrm{~m}\left(0.25 \mathrm{~m}^{2}\right)$ iron frame at two representative points of each plot. Then, the collected fragmented materials were dried in a forced air circulation and renovation oven at $60 \pm 5$ ${ }^{\circ} \mathrm{C}$, until a constant mass was reached.
Shoot dry matter (bean): the shoot dry matter mass production was estimated by the arithmetic mean of the two sampled points, with the mean values extrapolated to $\mathrm{kg} \mathrm{ha}^{-1}$. During the full flowering of the plants, eight plants were collected in sequence from the same line at a random point in the useful area, placed in properly identified paper bags, taken to the laboratory, and submitted for drying in a forced ventilation oven at $60 \pm 5^{\circ} \mathrm{C}$ until a constant mass was achieved. Subsequently, the samples were weighed and the values were converted to g plant $^{-1}$.

Production components: 10 plants were collected at harvest time from the useful area of the plots to evaluate the number of pods per plant (determined by the total number of pods/number of plants ratio), number of grains per plant (obtained by the total number of grains/number of plants ratio), average number of beans per pod (calculated by the total number of beans/total number of pods ratio), 100 grain weight (obtained by collecting and weighing three random samples of 100 grains per plot), and grain yield (three row plants of $3 \mathrm{~m}$ of the usable area of each plot were uprooted and left to dry in full sun). After drying, they were submitted to the mechanical trail, the grains were weighed, and the data were transformed into $\mathrm{kg} \mathrm{ha}^{-1}(13 \%$ wet basis).

In the statistical analysis, the data were subjected to analysis of variance by the $\mathrm{F}$ test. To verify the effect of the mulches, the averages were compared by Tukey's test at $5 \%$ probability. For the $\mathrm{N}$ doses, a regression analysis was performed according to the method proposed by Pimentel-Gomes and Garcia (2002). Statistical analyses were performed using the statistical analysis program SISVAR (Ferreira, 2011).

\section{Results and Discussion}

Regarding the dry matter values of plant residues present in the soil surface after the harvest of exclusive maize or intercropped maize, our results 
showed that all intercropped maize treatments had higher straw yields compared to the exclusive maize treatments. In the average of the two years of cultivation, the treatments intercropped with Crotalaria spectabilis, Cajanus cajan, Canavalia ensiformis, and Urochloa ruziziensis produced 2,032, 4,496, 1,978, and 3,952 $\mathrm{kg} \mathrm{ha}^{-1}$ more dry matter, respectively, than the exclusive maize treatments (Table 2).

\section{Table 2}

Dry matter of the vegetal cover present on the soil surface (previously cultivated with beans) after the harvest of the exclusive maize or intercropped maize. Selvíria - MS, 2014 and 2016

\begin{tabular}{|c|c|c|}
\hline \multirow{2}{*}{ Treatments } & \multicolumn{2}{|c|}{ Total dry matter $\left(\mathrm{kg} \mathrm{ha}^{-1}\right)$} \\
\hline & 2014 & 2016 \\
\hline Maize & $8,654 b$ & $6,827 \mathrm{~b}$ \\
\hline Maize + Crotalaria spectabilis & $11,167 \mathrm{a}$ & $8,377 \mathrm{~b}$ \\
\hline Maize + Cajanus cajan & $12,569 \mathrm{a}$ & $11,904 \mathrm{a}$ \\
\hline Maize + Canavalia ensiformis & $11,062 \mathrm{a}$ & $8,374 \mathrm{~b}$ \\
\hline Maize + Urochloa ruziziensis & $12,590 \mathrm{a}$ & $10,795 \mathrm{a}$ \\
\hline F test & $10.56^{* *}$ & $25.61^{* *}$ \\
\hline D.M.S & 2,227 & 1,827 \\
\hline CV (\%) & 8.81 & 8.76 \\
\hline
\end{tabular}

Corroborating the results of this work are the results of P. D. Oliveira, Kluthcouski, Favarin and Santos (2010) who evaluated a maize crop in a NTS, sown in consortium with cover crops (Crotalaria spectabilis, Cajanus cajan, or Urochloa ruziziensis); they observed that the intercropping of maize and covering plants produced a larger amount of dry matter (above $1200 \mathrm{~kg} \mathrm{ha}^{-1}$ ) in the cultivation area, compared to an exclusive maize cultivation.

In the first crop examined in the present study, all types of maize intercropped with cover crops produced a higher amount of dry matter compared to the exclusive maize crop. In the second crop, it was observed that the maize + Cajanus cajan and maize + Urochloa ruziziensis intercrops produced 11,904 and $10,795 \mathrm{~kg} \mathrm{ha}^{-1}$ of dry matter, respectively; these treatments were statistically superior to the other treatments with respect to the production of raw dry material. These consortia stood out for their higher dry matter production capacity, both in the first and second crop, in which they presented higher dry matter values than the other consortia. Similar results were obtained by Sabundjian, Arf, Kaneko and Ferreira (2013), who evaluated the agronomic characteristics and dry matter production of the intercropped maize + Urochloa ruziziensis cultivation; they observed that this intercropping increased the production of dry matter in the cultivation area by $28 \%$, guaranteeing $10,422 \mathrm{~kg}$ ha $^{-1}$ of vegetal cover for the successor crops.

These observations show that intercropping, compared to monoculture systems, promotes a richer and more diverse vegetation cover, thus contributing to the nutrition of subsequent crops. It is noteworthy that the input of high amounts of plant residues to the soil is one of the essential requirements for the success of NTS, especially in tropical conditions where the decomposition rate of the organic material is high. 
Regarding the agronomic characteristics and yield of beans, there was no significant interaction between the factors cover and doses of $\mathrm{N}$. It was also verified that there was no difference in the values obtained as a function of cover crops in the two years of cultivation; the exclusive maize or the maize intercropped with cover crops grown before the bean crop did not influence the evaluated parameters.
Regarding the number of pods per plant, number of grains per plant, and number of grains per pod obtained in the two years of cultivation, there was no effect of the treatments involving mulches (exclusive maize or intercropped with grass and legumes) and doses of $\mathrm{N}$ in coverage (Table 3). Even though there was an increase in dry plant matter (Table 4) with the increase in $\mathrm{N}$ rates, there was no influence on these production components.

Table 3

Number of pods per plant, number of grains per plant, and number of grains per pod obtained from beans grown after the cultivation of maize (exclusive or intercropped with cover crops) and as a function of nitrogen doses. Selvíria - MS, 2014 and 2016

\begin{tabular}{|c|c|c|c|c|c|c|}
\hline \multirow{2}{*}{ Treatments } & \multicolumn{2}{|c|}{ Pods plant $^{-1}$} & \multicolumn{2}{|c|}{ Grains plant $^{-1}$} & \multicolumn{2}{|c|}{ Grains pods $^{-1}$} \\
\hline & 2014 & 2016 & 2014 & 2016 & 2014 & 2016 \\
\hline \multicolumn{7}{|c|}{ Cover crops } \\
\hline Maize & 13.0 & 13.6 & 62.0 & 61.4 & 4.86 & 4.56 \\
\hline Maize + C. spectabilis & 12.9 & 13.7 & 61.8 & 66.1 & 4.91 & 4.82 \\
\hline Maize + C. Cajan & 12.6 & 14.3 & 60.1 & 67.3 & 4.79 & 4.70 \\
\hline Maize $+C$. ensiformis & 12.4 & 14.7 & 59.6 & 70.9 & 4.80 & 4.80 \\
\hline Maize + U. ruziziensis & 13.6 & 14.4 & 64.7 & 71.4 & 4.79 & 5.06 \\
\hline \multicolumn{7}{|c|}{$\mathbf{N}\left(\mathrm{kg} \mathrm{ha}^{-1}\right)$} \\
\hline 0 & 12.3 & 13.8 & 59.6 & 64.4 & 4.85 & 4.74 \\
\hline 40 & 12.5 & 14.8 & 60.2 & 71.2 & 4.83 & 4.79 \\
\hline 80 & 13.9 & 14.6 & 65.3 & 68.8 & 4.76 & 4.71 \\
\hline 120 & 12.9 & 13.4 & 61.4 & 65.4 & 4.86 & 4.90 \\
\hline F Cover crops & $0.76^{\mathrm{ns}}$ & $0.74^{\mathrm{ns}}$ & $0.77^{\text {ns }}$ & $2.00^{\mathrm{ns}}$ & $1.32^{\mathrm{ns}}$ & $1.54^{\mathrm{ns}}$ \\
\hline $\mathrm{F} \mathrm{N}$ rates & $2.61^{\mathrm{ns}}$ & $1.88^{\text {ns }}$ & $1.59^{\text {ns }}$ & $1.49^{\mathrm{ns}}$ & $1.31^{\mathrm{ns}}$ & $0.40^{\text {ns }}$ \\
\hline F Cover crops $\times \mathrm{N}$ & $0.45^{\text {ns }}$ & $1.98^{\mathrm{ns}}$ & $0.38^{\text {ns }}$ & $2.14^{\mathrm{ns}}$ & $1.45^{\mathrm{ns}}$ & $1.16^{\mathrm{ns}}$ \\
\hline CV (\%) & 15.54 & 16.00 & 14.86 & 17.03 & 3.90 & 12.54 \\
\hline
\end{tabular}

ns: not significant by the F test; CV: coefficient of variation.

In a study by Viana et al. (2011), examining the effect of different $\mathrm{N}$ doses on the common bean, a quadratic response was observed for the number of pods per plant, with the maximum point obtained with the dose of $108 \mathrm{~kg} \mathrm{ha}^{-1}$ of $\mathrm{N}$ in coverage, a fact that can be explained by the decrease of the population. As a result of increasing $\mathrm{N}$ rates, the compensation process occurred (a process in which bean plants have more pods due to the larger physical space for growth). The absence of significant differences for this parameter in the present study could be explained by the homogeneous plant population in the two years of cultivation, with an average of 210,000 plants ha $^{-1}$. 
Table 4

Plant dry matter, 100 grain weight, and grain yield of beans grown after the cultivation of maize (exclusive or intercropped with cover crops) and as a function of nitrogen doses. Selvíria - MS, 2014 and 2016

\begin{tabular}{|c|c|c|c|c|c|c|}
\hline \multirow[b]{2}{*}{ Treatments } & \multicolumn{2}{|c|}{ Dry matter $\left(\right.$ g plant $\left.^{-1}\right)$} & \multicolumn{2}{|c|}{100 grain weight (g) } & \multicolumn{2}{|c|}{ Productivity $\left(\mathrm{kg} \mathrm{ha}^{-1}\right)$} \\
\hline & 2014 & 2016 & 2014 & 2016 & 2014 & 2016 \\
\hline \multicolumn{7}{|c|}{ Cover crops } \\
\hline Maize & 6.25 & 8.11 & 24.37 & 25.58 & 2,908 & 3,781 \\
\hline Maize $+C$. spectabilis & 6.09 & 7.14 & 24.52 & 25.79 & 2,836 & 3,770 \\
\hline Maize + C. Cajan & 6.23 & 7.95 & 24.78 & 26.05 & 2,855 & 4,005 \\
\hline Maize $+C$. ensiformis & 6.34 & 8.01 & 24.81 & 25.65 & 2,929 & 3,928 \\
\hline Maize + U. ruziziensis & 6.08 & 8.53 & 24.43 & 26.30 & 2,881 & 4,010 \\
\hline \multicolumn{7}{|c|}{$\mathbf{N}\left(\mathbf{k g ~ h a}^{-1}\right)$} \\
\hline 0 & $5.78^{1}$ & $7.18^{2}$ & 24.95 & 25.77 & $2,796^{3}$ & 3,837 \\
\hline 40 & 6.15 & 7.35 & 24.49 & 25.57 & 2,827 & 3,945 \\
\hline 80 & 6.06 & 8.82 & 24.41 & 26.13 & 2,830 & 3,975 \\
\hline 120 & 6.79 & 8.44 & 24.49 & 26,03 & 3,074 & 3,837 \\
\hline F Cover crops & $0.22^{\mathrm{ns}}$ & $2.35^{\mathrm{ns}}$ & $1.25^{\mathrm{ns}}$ & $0.78^{\mathrm{ns}}$ & $0.47^{\mathrm{ns}}$ & $0.91^{\mathrm{ns}}$ \\
\hline $\mathrm{F} N$ rates & $3.93^{*}$ & $7.45^{* *}$ & $2.40^{\text {ns }}$ & $0.70^{\mathrm{ns}}$ & $6.70^{* *}$ & $0.44^{\mathrm{ns}}$ \\
\hline F Cover crops $\times N$ & $1.69^{\mathrm{ns}}$ & $1.01^{\mathrm{ns}}$ & $1.29^{\mathrm{ns}}$ & $0.64^{\mathrm{ns}}$ & $0.62^{\mathrm{ns}}$ & $0.96^{\mathrm{ns}}$ \\
\hline CV (\%) & 15.50 & 14.41 & 2.89 & 5.20 & 7.75 & 12.55 \\
\hline
\end{tabular}

Regarding the number of grains per pod, no differences were observed when it came to $\mathrm{N}$ rates, thus corroborating the results found by Chidi et al. (2002), Meira, Sá, Buzetti and Arf (2005), and Viana et al. (2011). The number of grains per pod is a varietal characteristic little influenced by the environment, thus being difficult to change (M. D. Andrade, Diniz, Carvalho, \& Lima, 1998).

Regarding the $\mathrm{N}$ rates in coverage, the results related to plant dry matter adjusted to an increasing linear function in the two years of cultivation, reaching 6.79 and $8.44 \mathrm{~g} \mathrm{plant}^{-1}$ in the first and second years, respectively, with a maximum dose of $120 \mathrm{~kg} \mathrm{~N} \mathrm{ha}{ }^{-1}$ (Table 4). Similarly, Chidi et al. (2002) and Crusciol, Soratto, Silva and Lemos (2007) observed a positive linear increase in the dry matter mass of bean plants with increased $\mathrm{N}$ rates in coverage, that was up to $120 \mathrm{~kg} \mathrm{ha}^{-1}$ in an NTS.
The increase in the dry matter production of bean shoots as a function of nitrogen fertilization is due to the increase in plant net photosynthesis caused by N (Soratto, Perez, \& Fernandes, 2014), since this nutrient makes up the chlorophyll molecule, which is responsible for photosynthesis (Arf, Rodrigues, Sá, Buzetti, \& Nascimento, 2004; Chidi et al., 2002; Crusciol et al., 2007). I. D. Oliveira and Thung (1988) observed that the maximum daily dry matter accumulation coincides with the period of higher $\mathrm{N}$ absorption, corroborating the data previously presented in the literature.

Regarding the weight of 100 grains, there was no effect of the treatments and the average values

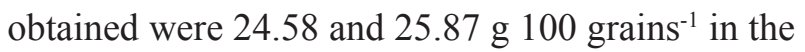
first and second year, respectively (Table 4). Similar results were obtained by Arf et al. (2004), Meira et al. (2005), Soratto, Carvalho and Arf (2004), and 
Viana et al. (2011), studying the effect of different $\mathrm{N}$ doses on common bean crops.

In both bean harvests, it was observed that there was no influence of vegetable residues on grain yield. For the $\mathrm{N}$ rates covered, in the first crop (2014) there was an adjustment to a growing linear equation, where there was an increase in grain yield as the $\mathrm{N}$ rates increased; in the second crop (2016) there was no difference in yield increase under the different $\mathrm{N}$ doses. The results of Gomes et al. (2008) who evaluated different rates of $\mathrm{N}$ coverage in bean crops, in an NTS cultivated after maize, and verified a linear behavior for yields up to $120 \mathrm{~kg} \mathrm{ha}^{-1}$ of $\mathrm{N}$, yielding 2,201 $\mathrm{kg} \mathrm{ha}^{-1}$ of grain, corroborate the results obtained from the first crop examined in this study. Valderrama et al. (2009) also describe linear responses of the grain yield of beans cultivated in NTS (up to $120 \mathrm{~kg} \mathrm{ha}^{-1} \mathrm{~N}$ ).

The average yield of our experiment was high $\left(2,882 \mathrm{~kg} \mathrm{ha}^{-1}\right.$ in the first crop and 3,899 $\mathrm{kg} \mathrm{ha}^{-1}$ in the second crop). The crop residues of exclusive or intercropped maize crops, coupled with the application of a small amount of $\mathrm{N}$ while sowing $\left(16 \mathrm{~kg} \mathrm{ha}^{-1}\right)$ and the contribution of the biological nitrogen fixation of the atmospheric air by the coinoculation of seeds with Rhizobium tropici and Azospirillum brasilense, resulted in a good nutrient intake.

Thus, only the first crop responded to N. In the second crop there was no need for nitrogen fertilization in coverage, since no significant differences were observed between the doses of $\mathrm{N}$. The absence of significant differences in the second year of cultivation regarding the $\mathrm{N}$ doses may be due to the fact that the nutrients coming from biological fixation and base fertilization in sowing, coupled with the mineralization of straw from previous crops between 2014 and 2016, were sufficient to meet the $\mathrm{N}$ demands of the crop. This was not the case in the first crop. According to Oliveira et al. (2010), the introduction of green manures in integrated production systems, in addition to allowing increased $\mathrm{N}$ input in the soil via biological fixation, promotes beneficial effects on subsequent cultivations, thus reducing the need for mineral $\mathrm{N}$ application.

Bordin et al. (2003) mention that the amount of N to be used in bean fertilization may be conditioned to the type of cover crop (grass or legume) cultivated in the area under an NTS. The authors observed that cultivating beans in succession to legumes provides higher yields with lower nutrient doses. On the other hand, in the present work there was no interaction between cover crops grown before beans and $\mathrm{N}$ rates in coverage. This result could be explained by the fact that the time the maize (exclusive or intercropped with cover crops) plant residues were mineralized did not allow for sufficient nutrient mineralization and availability to the bean crop, which was implanted in sequence. Torres, Pereira and Fabian (2008) studied the rate of nutrient mineralization of cover crops under winter conditions in the cerrado; they discovered that the half-life (period of time required for half of the nutrients contained in the residues to be released) of Cajanus cajan, Urochloa brizantha 'Marandu', and Crotalaria juncea crops for $\mathrm{N}$ was 66,78 , and 66 days, respectively, thus supporting the results of the present work.

In Selvíria - MS, Brazil, Gerlach (2014) evaluated the effects of different $\mathrm{N}$ rates $(0,30,60$, and 90 $\mathrm{kg} \mathrm{ha}^{-1}$ ) and soil cover on bean development. The results led the author to conclude that the mulching did not influence the yield components and yield of the common bean; on the other hand, the $\mathrm{N}$ rates in the mulching positively influenced the dry plant matter and grain yield, up to the maximum used dose of $90 \mathrm{~kg} \mathrm{ha}^{-1}$, as in the present study.

\section{Conclusions}

The intercropping of maize and cover crops led to an increase in the dry matter of the soil, compared to exclusive maize cultivations; although this 
intercropping provided adequate soil coverage, it did not influence the yield of the common bean that was cultivated in succession.

There was an increase in the dry matter of bean plants with $\mathrm{N}$ rates in the two years of cultivation; the pods plant ${ }^{-1}$, grains plant ${ }^{-1}$, grains pod $^{-1}$, and weight of 100 grains parameters were not influenced by cover plants or $\mathrm{N}$ doses.

The nitrogen fertilization in coverage led to increased productivity in the first crop, but had no effect on grain yield in the second crop.

\section{Acknowledgments}

We would like to thank Conselho Nacional de Desenvolvimento Científico e Tecnológico (CNPq) and Fundação de Amparo à Pesquisa do Estado de São Paulo (FAPESP) process 2013/19603-7 for founding the research.

\section{References}

Alvares, C. A., Stape, J. L., Sentelhas, P. C., Moraes, G. de, Leonardo, J., \& Sparovek, G. (2013). Köppen's climate classification map for Brazil. Meteorologische Zeitschrift, 22(6), 711-728. doi: 10.1127/0941-2948/2013/0507

Ambrosano, E. J., Wutke, E. B., Bulisani, E., \& Cantarella, H. (1997). Feijão. In B. van Raij, H. Cantarella, J. A. Quaggio, \& A. M. C. Furlani, Recomendações de adubação e calagem para o Estado de São Paulo. (Vol. 2, pp. 194-195) . Campinas: IAC.

Andrade, C. D. B., Patroni, S. M. S., Clemente, E., \& Scapim, C. A. (2004). Produtividade e qualidade nutricional de cultivares de feijão em diferentes adubações. Ciência e Agrotecnologia, 28(5), 10771086. doi: 10.1590/S1413-70542004000500015

Andrade, M. D., Diniz, A. R., Carvalho, J. D., \& Lima, S. D. (1998). Resposta da cultura do feijoeiro à aplicação foliar de molibdênio e às adubações nitrogenadas de plantio e cobertura. Ciência e Agrotecnologia, 22(4), 499-508.

Andrioli, I., Beutler, A. N., Centurion, J. F., Andrioli, F. F., \& Coutinho, E. L. M. (2008). Produção de milho em plantio direto com adubação nitrogenada e cobertura do solo na pré-safra. Revista Brasileira de Ciência do Solo, 32(4), 1691-1698. doi: 10.1590/ S0100-06832008000400034

Arf, O., Rodrigues, R. A. F., Sá, M. E. de, Buzetti, S., \& Nascimento, V. do. (2004). Manejo do solo, água e nitrogênio no cultivo de feijão. Pesquisa Agropecuária Brasileira, 39(2), 131-138. doi: 10.1590/S0100-204X2004000200005

Bordin, L., Farinelli, R., Penariol, F. G., \& Fornasieri, D., Fo. (2003). Sucessão de cultivo de feijão-arroz com doses de adubação nitrogenada após adubação verde, em semeadura direta. Bragantia, 62(3), 417428. doi: $10.1590 / \mathrm{S} 0006-87052003000300008$

Chidi, S. N., Soratto, R. P., Silva, T. D., Arf, O., Sá, M. E. de, \& Buzetti, S. (2002). Nitrogênio via foliar e em cobertura em feijoeiro irrigado. Acta Scientiarum, 24(5), 1391-1395. doi: 10.4025/actasciagron. v24i0.2387

Companhia Nacional de Abastecimento (2019). Acompanhamento da safra brasileira de grãos: safra 2018/19: Sexto levantamento. Brasília: CONAB. Recuperado de https://www.conab.gov.br/info-agro/ safras

Crusciol, C. A. C., Soratto, R. P., Silva, L. M. D., \& Lemos, L. B. (2007). Fontes e doses de nitrogênio para o feijoeiro em sucessão a gramíneas no sistema plantio direto. Revista Brasileira de Ciência do Solo, 31(6), 1545-1552. doi: 10.1590/S010006832007000600031

Doorenbos, J., \& Kassan, A. H. (1988). Efectos del agua sobre el rendimento de los cultivos. Riego y Drenaje, Roma: FAO.

Ferreira,D.F.(2011). Sisvar: a computer statistical analysis system. Ciência e Agrotecnologia, 35(6), 1039-1042. doi: 10.1590/S1413-70542011000600001

Food and Agriculture Organization of the United Nations (2017). Base de dados Faostat. Recuperado de http:// faostat.fao.org.

Gerlach, G. A. X. (2014). Consórcio entre milho e leguminosas, produção de palha e manejo do nitrogênio no feijão "de inverno" em região com verão chuvoso e inverno seco. Dissertação de mestrado, Universidade Estadual Paulista Júlio de Mesquita Filho, Ilha Solteira, SP, Brasil.

Gomes, F. G., Sá, M. E. de, \& Valério, W. V., Fº (2008). Nitrogênio no feijoeiro em sistema de plantio direto sobre gramíneas. Acta Scientiarum: Agronomy, 30(3), 387-395. doi: 10.4025/actasciagron.v30i3.3549 
Leite, L. F. C., Mendonça, E. S., Machado, P. L. O. A., \& Matos, E. S. (2003). Total C and N storage and organic C pools of a Red-Yellow Podzolic under conventional and no tillage at the Atlantic Forest Zone, south-eastern Brazil. Soil Research, 41(4), 717-730. doi:10.1071/SR02037

Meira F. A., Sá, M. E. de, Buzetti, S., \& Arf, O. (2005). Doses e épocas de aplicação de nitrogênio no feijoeiro irrigado cultivado em plantio direto. Pesquisa Agropecuária Brasileira, 40(4), 383-388. doi: 10.1590/S0100-204X2005000400010

Melo, C. L. P., Alvarez, R. C. F., Arf, O., Correa, A. M., Pereira, H. S., Melo, L. C., \& Faria, L. C. (2012). BRS Notável: nova cultivar de feijoeiro-comum semiprecoce do grupo carioca para Mato Grosso do Sul. (Comunicado Técnico, 179). Dourados, MS: Embrapa Agropecuária Oeste.

Oliveira, I. D., \& Thung, M. D. T. (1988). Nutrição mineral. Cultura do feijoeiro: fatores que afetam a produtividade. Piracicaba: Potafos.

Oliveira, P. D., Kluthcouski, J., Favarin, J. L., \& Santos, D. D. C. (2010). Sistema Santa Brígida-Tecnologia EMBRAPA: consorciação de milho com leguminosas. (Circular Técnica, INFOTECA-E). Santo Antônio de Goiás, GO: EMBRAPA Arroz e Feijão.

Pimentel-Gomes, F., \& Garcia, C. H. (2002). Estatística aplicada a experimentos agronômicos e florestais: exposição com exemplos e orientações pra uso de aplicativos. Piracicaba: FEALQ.

Raij, B. van, Andrade, J. C., Cantarella, H., \& Quaggio, J. A. (2001). Análise química para avaliação da fertilidade de solos tropicais. Campinas: IAC.

Rao, R. B., \& Li, Y. C. (2003). Nitrogen mineralization of cover crop residues in calcareous gravelly soil. Communications in Soil Science and Plant Analysis, 34(3-4), 299-313. doi: 10.1081/CSS-120017822

Sabundjian, M. T., Arf, O., Kaneko, F. H., \& Ferreira, J. P. (2013). Adubação nitrogenada em feijoeiro em sucessão a cultivo solteiro e consorciado de milho e Urochloa ruziziensis. Pesquisa Agropecuária Tropical, 43(3), 292-299. doi: 10.1590/S198340632013000300007

Santos, H. G., Jacomine, P. K. T., Anjos, L. H. C., Oliveira, V. A., Lumbreras, J. F., Coelho, M. R.,... Cunha, T. J. F. (2018). Sistema brasileiro de classificação de solos. (5a ed.). Brasília: Embrapa.
Silva, T. R. B., Lemos, L. B., \& Tavares, C. A. (2006). Produtividade e característica tecnológica de grãos em feijoeiro adubado com nitrogênio e molibdênio. Pesquisa Agropecuária Brasileira, 41(5), 739-745. doi: 10.1590/S0100-204X2006000500004

Siqueira, M., Neto, Piccolo, M. C. de, Venzke, S. P., Fo., Feigl, B. J., \& Cerri, C. C. (2010). Mineralização e desnitrificação do nitrogênio no solo sob sistema plantio direto. Bragantia, 69(4), 923-936. doi: 10.1590/S0006-87052010000400019

Soratto, R. P., Carvalho, M. A. C., \& Arf, O. (2004). Teor de clorofila e produtividade do feijoeiro em razão da adubação nitrogenada. Pesquisa Agropecuária Brasileira, 39(9), 895-901. doi: 10.1590/S0100204X2004000900009

Soratto, R. P., Crusciol, C. A. C., Silva, L. M., \& Lemos, L. B. (2005). Aplicação tardia de nitrogênio no feijoeiro em sistema de plantio direto. Bragantia, 64(2), 211218. doi: 10.1590/S0006-87052005000200007

Soratto, R. P., Perez, A. A. G., \& Fernandes, A. M. (2014). Age of no-till system and nitrogen management on common bean nutrition and yield. Agronomy Journal, 106(3), 809-820. doi: 10.2134/agronj13.0439

Steenwerth, K., \& Belina, K. M. (2008). Cover crops enhance soil organic matter, carbon dynamics and microbiological function in a vineyard agroecosystem. Applied Soil Ecology, 40(2), 359369. doi: 10.1016/j.apsoil.2008.06.006

Torres, J. L. R., Pereira, M. G., \& Fabian, A. J. (2008). Produção de fitomassa por plantas de cobertura e mineralização de seus resíduos em plantio direto. Pesquisa Agropecuária Brasileira, 43(3), 421-428. doi: 10.1590/S0100-204X2011000100003

Valderrama, M., Buzetti, S., Sabin-Benett, C. G., Andreotti, M., Arf, O., \& Sá, M. E. de. (2009). Fontes e doses de nitrogênio e fósforo em feijoeiro no sistema plantio direto. Pesquisa Agropecuária Tropical, 39(3), 191-196. doi: 10.5216/pat. v39i3.4987

Viana, T. O., Vieira, N. M. B., Moreira, G. R. L., Batista, R. O., Carvalho, S. J. P., \& Rodrigues, H. F. F. (2011). Adubação do feijoeiro cultivado no norte de Minas Gerais com nitrogênio e fósforo. Revista Ceres, 58(1), 115-120. doi: 10.1590/S0034737X2011000100017 
